\title{
INSTRUMENTI ZAŠTITE VJEROVNIKA DRUŠTAVA KAPITALA KOJA SUDJELUJU U PREKOGRANIČNIM PRIPAJANJIMA I SPAJANJIMA U POLJSKOM TE SLOVAČKOM PRAVU
}

Doc. dr. sc. Mateusz Żaba*

\author{
UDK 347.72.036 \\ https://doi.org/10.30925/zpfsr.42.1.10 \\ Pr.: 9. svibnja 2020. \\ Ur.: 20. srpnja 2020. \\ Pregledni rad
}

\begin{abstract}
Sažetak
Prekogranična pripajanja i spajanja sve su češći predmet analize u pravnoj doktrini država članica Europske unije. Pripajanje i spajanje između društava iz različitih država temelji se na načelu djelovanja jedinstvenog tržišta $u$ Europskoj uniji. Prekogranično pripajanje ili spajanje nosi sa sobom niz pravnih posljedica $i$ utječe na položaj dosadašnjih vjerovnika društava koja sudjeluju u tim postupcima. U radu su detaljno obrađeni mehanizmi koji služe zaštiti interesa vjerovnika društava kapitala koja sudjeluju u pripajanju $i$ spajanju prema poljskom i slovačkom zakonodavstvu. Pri izboru analiziranih pravnih poredaka uzeto je u obzir da su te zemlje u posljednjih trideset godina prošle preobliku državnog uređenja, stvorile nove mogućnosti za gospodarske djelatnosti u sklopu slobodnoga tržišnog gospodarstva i postale države članice Europske unije 1. svibnja 2004. U radu se ponajprije analizira zaštita interesa vjerovnika na institucionalnoj $i$ individualnoj razini. U posebnim su poglavljima predstavljeni instrumenti povezani $s$ opisanom tematikom, primjerice odgovornost društva slijednika za obveze, odvojeno upravljanje imovinom, prvenstveno pravo namirenja iz imovine društva dužnika i pravo zahtijevati davanje osiguranja tražbina.
\end{abstract}

Ključne riječi: prekogranično pripajanje; prekogranično spajanje; zaštita vjerovnika; poljsko zakonodavstvo; slovačko zakonodavstvo; institucionalna zaštita interesa vjerovnika društva; individualna zaštita interesa vjerovnika društva.

* Dr. sc. Mateusz Żaba, docent, Fakultet prava i uprave Šleskog sveučilišta u Katowicama; mateusz.zaba@us.edu.pl. ORCID: https://orcid.org/0000-0002-3636-6456.

Ovaj je rad nastao uz potporu slovačke Agencije za potporu istraživanja i razvoja (slov. Agentúra na podporu výskumu a vývoja) na temelju Ugovora br. APVV-19-0424. 


\section{1. $U$ VOD}

Zaštita interesa vjerovnika društva koje sudjeluje u postupku pripajanja ili spajanja nesumnjivo je jedno od najvažnijih pitanja u pravu društava. I unutarnja i prekogranična spajanja i pripajanja mogu povlačiti za sobom rizik povrede prava dosadašnjih poslovnih partnera društva koje sudjeluje u tom postupku. Razlog za zaštitu vjerovnika društva koje sudjeluje u prekograničnom pripajanju (odnosno spajanju) ponajprije će biti: prijenos imovine pripojenih društava (odnosno sudjelujućih u spajanju) društvu preuzimatelju (odnosno novomu društvu); moguća promjena mjerodavnog prava za društvo koje postaje pravni sljednik te zabrana proglašavanja ništetnim prekograničnog pripajanja (spajanja) koje je bilo upisano u nadležni registar. Spomenute pravne posljedice prekograničnog pripajanja (spajanja) društava kapitala posljedično mogu utjecati na mogućnost namirenja tražbina vjerovnika pripojenog društva ili društva kapitala koje se spaja. S obzirom na to, regulatornim okvirom će se odrediti zaštita vjerovnika, u postupku pripajanja i spajanja društava. ${ }^{1}$ Ograničenje u uređenju ove problematike je pružanje vjerovnicima prikladne zaštite tako da za društvo, koje sudjeluje u pripajanju ili spajanju, neće biti nametnute prekomjerne obveze.

Poljski je zakonodavac pripajanje i spajanje društava uredio u sklopu dijela I. glave IV. Zakonika o trgovačkim društvima (polj. Kodeks spótek handlowych). ${ }^{2}$ Ova regulacija obuhvaća skoro četrdeset članaka koji se odnose na unutarnja spajanja i pripajanja društava te devetnaest članaka koji se tiču prekograničnoga spajanja i pripajanja društava. Nadalje nužno je istaknuti da prema sadržaju odredbe članka 516(1). poljskoga ZoTD-a, prekogranična pripajanja (spajanja) podliježu odredbama poglavlja 2. koje se tiče unutarnjih pripajanja (spajanja), osim ako odredbama navedenog poglavlja 2(1)., koje se tiču prekograničnog pripajanja (spajanja) nije određeno drukčije. Uzimajući u obzir spomenute pravne instrumente, zaštitu vjerovnika poljskoga društva koje sudjeluje u prekograničnom spajanju uređuju članci 494. § 1, 495. i 496., 516(4). i 516(10). ZoTD-a.

U slovačkom zakonodavstvu pripajanje i spajanje društva uređeno je u propisima Trgovačkog zakonika (slov. Obchodný zákonnik). ${ }^{3}$ Slovačko je pravo usvojilo drukčiju usustavljenost uređenja odredaba koje se tiču pripajanja i spajanja društava nego poljsko pravo. U odredbama § 69.-69. a slovačkoga Trgovačkog zakonika predviđene su, tzv. opće odredbe o pripajanjima (spajanjima) i podjelama društava koja imaju registrirano sjedište na području Republike Slovačke. Međutim, § 69. aa obuhvaća opće odredbe koje se odnose na prekogranična pripajanja i

1 Vidi Wojciech Jerzy Katner i Krzysztof Fliszkiewicz, "Łączenie się i inne rodzaje transformacji spółek ze szczególnym uwzględnieniem ochrony wierzycieli łączących się spółek kapitałowych (prawo polskie na tle prawa Unii Europejskiej)", u: Kodeks spółek handlowych po dziesięciu latach, ed. Józef Frąckowiak, (Wrocław: Wydawnictwo Uniwersytetu Wrocławskiego, 2013.), 711.

2 Ustawa z 15.08.2000 r. - Kodeks spótek handlowych od 15. kolovoza 2000. (hrv. Zakonik o trgovačkim društvima) - Dz. U. z 2000 r., nr 94, poz. 1037 wraz ze zm. (dalje: ZoTD).

3 Zákon z 5.11.1991 - Obchodný zákonník od 5. studenoga 1991. (hrv. Trgovački zakonik) - Zák. č. 513/1991 Z. z., (dalje: slovački TZ). 
prekogranična spajanja. Odredbe § 69.-69. a ishodište su za zakonsko uređenje prekograničnoga pripajanja i spajanja. ${ }^{4} \mathrm{Uz}$ to, posebne odredbe koje se odnose na pripajanja društava kapitala nalaze se u $\S 152$. a te $\S 218$. a - 218. lk slovačkoga TZ-a. Osnovni dio odredaba koje se odnose na zaštitu vjerovnika pri prekograničnim pripajanjima (spajanjima) smješten je u $§ 69$. aa slovačkoga TZ-a.

Komplicirano pitanje zaštite interesa vjerovnika potkrijepljuje činjenica da spomenute dvojbe nemaju jedino teorijsko-pravni značaj, već se odnose i na praktične probleme. S obzirom na to, ovim pitanjima bit će posvećena posebna pažnja u ovom članku. Primjenom usporednopravne metode analiziran je institut zaštite vjerovnika društava koji je prvotno bio oblikovan još u unutarnjim pravnim poredcima, a zatim i dopunjen primjenom Direktive Vijeća od 9. listopada 1978. o spajanjima dioničkih društava ${ }^{5}$ te Direktivom 2005/56/EZ Europskog parlamenta i Vijeća od 26. listopada 2005. o prekograničnim spajanjima društava kapitala. ${ }^{6}$

\section{INSTITUCIONALNA I INDIVIDUALNA ZAŠTITA INTERESA VJEROVNIKA}

Zaštita interesa vjerovnika u slučaju prekograničnog pripajanja (spajanja) uređena je na dvjema razinama: institucionalnoj i individualnoj. Kako se ističe u doktrini, ${ }^{7}$ institucionalna razina zaštite vjerovnika temelji se na objektivnom pravu i ima zaštitni karakter. Dakle, ne stvara izravnu mogućnost za individualnu zaštitu subjektivnih prava pojedinačnih vjerovnika. Institucionalna zaštita, za razliku od individualne zaštite, ne zahtijeva djelovanja vjerovnika u svrhu njihove realizacije. Ova zaštita pripada ex lege i u pravilu stvara uvjete za traženje prava vjerovnika.

U državnim pravnim poredcima, u mehanizme, koji pružaju institucionalnu razinu zaštite interesa vjerovnika, mogu se ubrojiti:

1. obveze društava koja sudjeluju u pripajanjima (spajanjima) sastavljati izvješće o takvom postupku prema vjerovnicima;

2. revizija zajedničkoga plana pripajanja (spajanja) koju provodi neovisni revizor;

4 Vidi Zuzana Bartová, u: Maria Patakyová et al., Obchodný zákonnik. Komentár, (Bratislava: C.H. Beck, 2010.), § 69aa ObZ,243.

5 Treća direktiva Vijeća od 78/855/EEZ od 9. listopada 1978. o spajanjima dioničkih društava, Službeni list br. 295, 20. listopada 1978. Trenutačno ovu materiju uređuje Direktiva Europskog parlamenta i Vijeća (EU) 2017/1132 od 14. lipnja 2017. o određenim aspektima prava društava.

6 Deseta direktiva 2005/56/EZ Europskog parlamenta i Vijeća od 26. listopada 2005. o prekograničnim pripajanjima i spajanjima društava kapitala, Službeni list br. 310, 25. studenoga 2005. Aktualno, u vezi sa stavljanjem izvan snage Treće i Desete direktive, pitanje tuzemnog i prekograničnog pripajanja te spajanja regulirano je izravno u odredbama Direktive Europskog parlamenta i Vijeća (EU) 2017/1132 od 14. lipnja 2017. o određenim aspektima prava društava.

$7 \mathrm{Na}$ tu temu vidi: Susanne Kalls, „Gläubigerschutz bei Verschmelzungen von Kapitalgesellschaften“, Zeitschrift für Unternehmens- und Gesellschaftsrecht, br. 1 (2009): 80 i dalje te Radovan Pala, Ivana Palová i Andrej Leontiev, Cezhraničné fúzie (Bratislava: C.H. Beck, 2010.), 182; Mateusz. Żaba, Skutki transgranicznego taczenia się spótek kapitałowych (studium prawnoporównawcze ustawodawstwa polskiego, czeskiego i słowackiego) (Warszawa: C.H. Beck, 2019.), 235-236. 
3. ispitivanje zakonitosti prve etape prekograničnog pripajanja (spajanja) i postupka izdavanja potvrde koje potvrđuju da je postupak proveden u skladu sa zakonskim odredbama i

4. revizija prekograničnog pripajanja (spajanja) i upis u registar nadležnog tijela.

Međutim, individualnu razinu zaštite interesa vjerovnika izravno određuju subjektivna prava koja ima vjerovnik. Individualna zaštita neposredno služi osiguranju ili namirenju vjerovnikovih tražbina prema društvu-dužniku koje sudjeluje u prekograničnom pripajanju (spajanju). Ova zaštita, iako se primjenjuje po sili zakona, zahtijeva aktivno djelovanje vjerovnika. ${ }^{8}$ Tek aktivnom radnjom vjerovnika može doći do stvarne zaštite njegovih interesa i namirenja njegove tražbine.

S obzirom na različita pravna rješenja koja su bila donesena u zakonodavstvima, zaštita interesa vjerovnika može biti ostvarena, između ostalog, na temelju:

- prava zahtijevanja osiguranja ili namirenje tražbina;

- prava zahtijevanja naknade štete članovima organa društva koje sudjeluje u prekograničnim pripajanjima (spajanjima) ${ }^{9}$

- drugih oblika koji imaju svoj izvor izravno u obveznom pravu ${ }^{10}$ ili u ugovornim odnosima (sporazumima) između pripajajućih društava.

\section{INSTRUMENTI INSTITUCIONALNE ZAŠTITE}

\subsection{Poljska regulacija}

\subsubsection{Odgovornost društva slijednika za obveze i odvojeno upravljanje imovinom}

Pripajanje (spajanje) društava kapitala, i unutarnje i prekogranično, proizvodi određene pravne učinke. U poljskom pravu učinci u pravilu nastupaju danom upisa pripajanja u registar poljskoga registarskog suda, tzv. dan provođenja pripajanja (spajanja) (polj. dzień połaczenia). Međutim, to se odnosi samo kada društvo preuzimatelj ili novo društvo ima sjedište na području Republike Poljske. Bez obzira na to u kojoj državi članici EU-a će imati svoje sjedište društvo preuzimatelj ili novo društvo, na njega će u osnovi prelaziti imovina, pripojenih društava ili društava koja sudjeluju u spajanju. Osim prava i imovine, društvo preuzimatelj ili novo društvo preuzimaju danom provođenja pripajanja (spajanja) i obveze pripojenih društava ili društava koja sudjeluju u spajanju. Time dosadašnji vjerovnici društava koja prestaju u postupku pripajanja ili spajanja dobivaju novog dužnika. Tim je uređenjem zajamčena minimalna zaštita interesa vjerovnika, jer će oni moći sačuvati svoja

8 Vidi Kalls, Gläubigerschutz bei Verschmelzungen von Kapitalgesellschaften, 81 te Pala, Palová, Leontiev, Cezhraničné fúzie, 182.

9 Ovo pravo ovisi o tome predviđa li konkretno zakonodavstvo mogućnost pozivanja na odgovornost članova upravljačkih ili upravnih organa vjerovnika društva koje sudjeluje u pripajanju i spajanju.

10 Npr. Paulijanska tužba. 
prava koja su im ranije pripadala u društvu koje prestaje pripajanjem ili spajanjem. ${ }^{11}$ U odnosu na vjerovnike pripojenog društva ili društva koje sudjeluje u spajanju, promjena se dužnika provodi bez potrebe njihova pristanka. Posljedično dolazi do sveopćega pravnog sljedništva.

$\mathrm{Na}$ temelju jednoga jedinstvenog pravnog akta društvo preuzimatelj, odnosno novo društvo, stupa u imovinsko-pravni položaj pripojenog društva, odnosno onog koje sudjeluje u spajanju. U poljskoj se pravnoj literaturi navodi da u vezi s tim nije neophodno određivati u sklopu plana pripajanja (spajanja) imovinu ili obveze društva, jer svi oni u pravilu prelaze na društvo preuzimatelja, odnosno na novo društvo. ${ }^{12}$

Imovina društva preuzimatelja ili novoga društva nakon provođenja pripajanja (spajanja) u osnovi je jedinstvena cjelina. Ipak, s obzirom na mogućnost povrede interesa vjerovnika društava koja sudjeluju u pripajanjima ili spajanjima, poljski je zakonodavac propisao u članku 495. ZoTD-a sustav njihove zaštite u obliku odvojenog upravljanja imovinom takvih društava. Ova će se odredba primijeniti i kod prekograničnih pripajanja i spajanja, ako je za društvo preuzimatelja ili novo društvo mjerodavno poljsko pravo. Poljski je zakonodavac na isti način izašao izvan minimalnog standarda usklađivanja koji je trenutačno uređen u članku 99. Direktive 2017/1132/EU.

Nužno je istaknuti kako je pravna konstrukcija odvojenog upravljanja imovinom društava koja sudjeluju u pripajanjima ili spajanjima bila usvojena još u odredbama poljskoga Trgovačkog zakonika iz $1934 .{ }^{13}$ Inspiracija za njezino donošenje bio je njemački model zaštite vjerovnika u slučaju pripajanja utemeljenog na, tzv. separatio bonorum - pravnom institutu nasljednog prava. ${ }^{14}$

Odredba članka 495. § 1. ZoTD-a uređuje expressis verbis da imovinom svakoga društva koje se pripojilo ili spojilo treba odvojeno upravljati društvo preuzimatelj ili novo društvo do dana namirenja ili osiguranja vjerovnika. Nadalje, namirenje ili osiguranje mora se dati ako su tražbine nastale prije dana provođenja pripajanja (spajanja). Vjerovnicima je dana mogućnost traženja osiguranja ili podmirenja njihovih tražbina uz uvjet da u roku od šest mjeseci od objave upisa pripajanja (spajanja) u sudski registar, podnesu društvu pisani zahtjev. Poljski zakonodavac ne spominje sankcije pri nepoštovanju pisanoga oblika zahtjeva. U vezi s tim nužno je imati na umu da pisani oblik, u kojem mora biti podnesen zahtjev vjerovnika, označava jedino formu ad probationem. ${ }^{15}$ Naime, čak će usmeni zahtjev

11 Vidi Krzysztof Fliszkiewicz, Ochrona wierzycieli łączacych się spółek kapitałowych (Warszawa: C.H. Beck, 2016.), 91.

12 Usporediti s Andrzej Szumański, u: Kodeks spólek handlowych. Komentarz. Tom IV, eds. S. Sołtysiński et al. (Warszawa: C.H. Beck, 2012.), Art. 494 KSH Nb. 9, 92.

13 Ustawa z 27.06.1934 r. - Kodeks handlowy" od 27. lipnja 1934. (hrv. Trgovački zakonik) - Dz. U. z 1934 r., nr 57, poz. 502 wraz ze zm.

14 Više vidi u: Katner, Fliszkiewicz, „Łączenie się i inne rodzaje transformacji spółek ze szczególnym uwzględnieniem ochrony wierzycieli łączących się spółek kapitałowych (prawo polskie na tle prawa Unii Europejskiej)", 718-719; Fliszkiewicz, Ochrona wierzycieli łaczacych się spótek kapitałowych, 183.

15 Slično kod: Mateusz Rodzynkiewicz, u: Adam Opalski (ur.) Kodeks spótek handlowych. Tom IV. Łączenie, podziat, przekształcanie spółek. Przepisy karne. Komentarz (Warszawa: C.H. 
vjerovnika upućen u zakonskom roku proizvesti obvezu odvojenog upravljanja imovinama. Vjerovnik pritom može imati samo poteškoće u dokazivanju da je zahtijevao isplatu od društva. Uz to, zahtjev postavljen u pisanom obliku moraju potpisati osobe koje imaju pravo zastupati vjerovnika (npr. u skladu s društvenim ugovorom ili statutom). ${ }^{16}$ Međutim, prema članku 78. § 2. poljskoga Građanskog zakonika, ${ }^{17}$ kao ekvivalentna izjavi volje danoj u pisanom obliku smatra se izjava volje dana u elektroničkom obliku i potpisana kvalificiranim elektroničkim potpisom (polj. kwalifikowany podpis elektroniczny).

Usprkos dikciji odredbe članka 495. § 1. ZoDT-a nužno je usuglasiti se sa stajalištem zauzetim u doktrini da u tom slučaju nije riječ o odvojenom upravljanju imovinama društava koja su se pripojila (spojila) u ekonomskom smislu. ${ }^{18}$ Pod pojmom „odvojeno upravljanje” treba razumjeti administriranje, nadzor i skrb nad imovinama društava koja sudjeluju u pripajanjima (spajanjima). Pritom je nužno imati na umu da će u tom slučaju za imovinu takvih društava morati postojati odvojeni bankarski računi i da će se transakcije morati bilježiti odvojeno. ${ }^{19}$

$\mathrm{Za}$ vođenje odvojenog upravljanja imovinama odgovaraju članovi organa društva preuzimatelja ili novog društva (čl. 495. § 2. ZoTD-a). Ova se odgovornost tiče članova uprave, nadzornog odbora te likvidatora. ${ }^{20} \mathrm{Te}$ su osobe odgovorne prema vjerovnicima društava koja su sudjelovala u pripajanju, odnosno spajanju. Nadalje, takva odgovornost ima solidaran i osoban karakter, a članovi organa društva kapitala odgovarat će za vođenje odvojenog upravljanja neograničeno cijelom svojom imovinom. Valja se složiti sa stajalištem da ta odgovornost ima deliktan karakter. ${ }^{21}$ Šteta će se vjerovnika temeljiti na tome što on neće moći namiriti svoju tražbinu nastalu prije dana provođenja pripajanja (spajanja) u punom opsegu u vezi s pogrešno vođenim odvojenim upravljanjem imovinama društva.

Obrazloženje pravnog stajališta odvojenog upravljanja imovinama društava koje sudjeluju u postupku pripajanja ili spajanja nije zaštita društva dužnika, već zaštita vjerovnika tog društva. Cilj je usvojenog rješenja ne samo zaštita vjerovnika

Beck, 2016.), Art. 495 KSH Nb. 8, 144; Szumański, Kodeks spótek handlowych. Komentarz. Tom IV, Art. 495 KSH Nb. 27, 127; Krzystof Oplustil, u: Jacek Bieniak et al., Kodeks spótek handlowych. Komentarz, (Warszawa: C.H. Beck, 2015.), Art. 495 KSH Nb. 2, 1145.

16 Uporediti s: Krzystof Oplustil, u: Jacek Bieniak et al., Kodeks spótek handlowych. Komentarz, (Warszawa: C.H. Beck, 2015.), Art. 495 KSH Nb. 21145.

17 Ustawa z 23.04.1964 - Kodeks cywilny od 23. ožujka 1964. (hrv. Građanski zakonik) - Dz. U. $\mathrm{Nr} 16$, poz. 93 ze zm (dalje: GZ).

18 Vidi: Fliszkiewicz, Ochrona wierzycieli łaczacych się spółek kapitałowych, 186-187.

19 Vidi: Antoni Witosz, Łączenie się i podziat spółek w Kodeksie spótek handlowych, Bydgoszcz: Branta, 2002, 98; Grzegorz Kozieł, Rozdział IX.10 u: Andrzej Kidyba, Prawo spótek, Warszawa: Wolters Kluwer, 2013., 1668 i Piotr Pinior, u: Janusz Andrzej Strzępka, (ur.), Kodeks spółek handlowych. Komentarz, (Warszawa: C.H. Beck, 2015.), Art. 495 KSH Nb. 2. 1208.

20 Vidi: Pinior, u: Strzępka . (ur.), Kodeks spótek handlowych. Komentarz (Warszawa: C.H. Beck, 2015.), Art. 495 KSH Nb. 2,. 1209; Marta Skrodzka i Karol Skrodzki, u: Zbigniew Jara (ur.), Kodeks spótek handlowych. Komentarz, (Warszawa: C.H. Beck, 2014.), Art. 495 KSH, 1757.

21 Više vidi: Rodzynkiewicz, u: Opalski (ur.), Kodeks spótek handlowych. Tom IV. Eaczenie, podziat, przeksztatcanie spótek. Przepisy karne. Komentarz, (Warszawa: C.H. Beck, 2016.), Art. 495 KSH Nb. 12, 145; Pinior, u: Strzępka, (ur.), Kodeks spótek handlowych. Komentarz, (Warszawa: C.H. Beck, 2015.), Art. 495 KSH Nb. 3, 1209. 
od društva dužnika, već i zaštita jedne grupe vjerovnika od druge. ${ }^{22}$ Odvojeno upravljanje imovinama u početnom stadiju pripajanja, odnosno spajanja, vodi izbjegavanju posljedica univerzalnog sljedništva. Kod nepostojanja zakonske odredbe posljedica bi bila jedinstvena imovinska masa sastavljena od aktiva svih društava koja sudjeluju u postupcima pripajanja ili spajanja. Drugim riječima, vjerovnik bilo kojega društva mogao bi podmiriti svoje tražbine iz aktive bez obzira na to jesu li ona prvotno pripadala društvu koje je bilo njegov dužnik.

\subsubsection{Obveza objavljivanja podataka društava koja sudjeluju u prekograničnom pripajanju $i$ spajanju}

Sljedeći mehanizam institucionalne zaštite interesa vjerovnika u slučaju prekograničnog pripajanja (spajanja) obveza je objave zajedničkoga plana pripajanja (spajanja). Ovaj je institut uređen u odredbama poglavlja 2(1). dijela I., glave IV. poljskoga Zakonika o trgovačkim društvima. U smislu odredbe članka 516(4). § 1. ZoTD-a društvo mora objaviti zajednički plan pripajanja (spajanja) najmanje mjesec dana prije negoli što se sazove skupština članova d.o.o. ili glavna skupština ${ }^{23}$ na kojoj se donosi odluka o pripajanju (spajanju). Uz to, zakonodavac predviđa iznimno mogućnost odstupanja od objave plana ako društvo učini plan javno dostupnim na mrežnim stranicama, no ne kasnije od mjesec dana prije održavanja skupštine pa do njezina zaključenja. Plan mora biti dostupan neprekidno do toga trenutka. Ova je odredba adresirana na poljsko društvo kapitala koje sudjeluje u prekograničnom pripajanju (spajanju). To znači da je rok za objavu zajedničkoga plana pripajanja (spajanja) određen donošenjem odluke poljskoga društva, bez obzira na trenutak odluke stranog društva.

Spomenuta odredba uređuje poseban mehanizam koji omogućuje da se vjerovnika upozna sa zajedničkim planom pripajanja (spajanja). U planu se moraju navesti svi podatci koji se tiču uvjeta ostvarivanja prava vjerovnika i adrese na kojoj se bez naknade mogu dobiti cjelokupni podatci o uvjetima i formalna mogućnost provođenja prava vjerovnika na namirenje ili osiguranje tražbine.

Zajednički plan pripajanja (spajanja) mora se objaviti u Sudskom i gospodarskom monitoru (polj. Monitor Sadowy i Gospodarczy). S obzirom na ulogu i dikciju odredbe članka 516(4). ZoTD-a smatra se da vjerovnici društava moraju imati zajamčenu mogućnost upoznati se s planom pripajanja (spajanja) najkasnije mjesec dana prije održavanja skupštine na kojoj će se odlučivati o pripajanju, odnosno spajanju.

22 Uporediti sa: Fliszkiewicz, Ochrona wierzycieli łączacych się spótek kapitałowych, 188.

23 Nužno je istaknuti da je poljski zakonodavac predvidio u slučaju društva s ograničenom odgovornošću da je jedan od njegovih tijela skupština članova d.o.o. (polj. zgromadzenie wspólników spółki z o.o.). Međutim, u odnosu na dioničko društvo - to je tijelo glavna skupština (polj. walne zgromadzenie). 


\subsubsection{Sudsko ispitivanje prekograničnog pripajanja ili spajanja društava kapitala}

Zaštita interesa vjerovnika društava kapitala koja sudjeluju u prekograničnom pripajanju i spajanju neizravno se ostvaruje i zbog izdavanja ili odbijanja izdavanja potvrde o zakonitosti prekograničnog pripajanja ili spajanja. Dodatno, ako je za društvo preuzimatelja ili novo društvo mjerodavno poljsko pravo, registarski sud, nakon podnošenja prijave za upis pripajanja ili spajanja, ima pravo ispitivati jesu li društva odobrila zajednički plan uz iste uvjete. Nužno je naglasiti da poljski zakonodavac predviđa dvije etape sudske kontrole prekograničnog pripajanja ili spajanja koje mogu biti određene kao instrumenti služeći institucionalnoj zaštiti interesa vjerovnika.

Izdavanje potvrde o zakonitosti prekograničnog pripajanja ili spajanja po poljskom je pravu prva etapa postupka nadzora. Nadležnost je registarskog suda bila u pravilu ograničena odredbom članka 23. Zakona o Državnom sudskom registru (polj. ustawa Krajowym Rejestrze Sadowym). Prema tom članku, registarski je sud ovlašten ispitati jesu li priloženi dokumenti u pogledu forme i sadržaja u skladu sa zakonom.

Drugu će etapu kontrole izvršiti nadležno tijelo ovlašteno za upis prekograničnoga pripajanja i spajanja. U poljskom pravu ovo pitanje uređuje odredba članka 516(13). ZoTD-a. Pritom je nužno istaknuti da poljski zakonodavac nameće ovu obvezu upravi poljskog društva ako je društvo preuzimatelj u slučaju prekograničnog pripajanja, kao i na upravne organe društava koja sudjeluju u spajanju, ako će za novo društvo biti mjerodavno poljsko pravo. Prema toj odredbi spomenuti su organi obvezni podnijeti prijavu za upis u registarski sud u čijem je registru upisano društvo preuzimatelj, odnosno u kojem će biti upisano novo društvo. Uz prijavu mora biti dostavljena potvrda o zakonitosti prekograničnog pripajanja, odnosno spajanja, s nacionalnim pravima društava koja sudjeluju u postupku. Ove potvrde ne mogu biti izdane prije protjeka roka od šest mjeseci od dana prijave (čl. 516(13). § 2. toč. 1. ZoTD-a). Time ponovo dolazi do kontrole zakonitosti postupka, ali sada je obavlja registarski sud nadležan za društvo koje će biti pravni sljednik društava koja sudjeluju u pripajanju, odnosno spajanju.

\subsection{Slovačka regulacija}

\subsubsection{Odgovornost društva sljednika za obveze}

Slovački zakonodavac određuje da provođenjem pripajanja društvo preuzimatelj postaje pravni sljednik pripojenih društava i analogno, novoosnovano društvo postat će pravni sljednik društava koja su sudjelovala u spajanju. Odredba $\S$ 69. stavak 3. od. 1. slovačkoga Trgovačkog zakonika u odnosu na pripajanja te $\S$ 69. stavak 3. od. 1. slovačkoga Trgovačkog zakonika u odnosu na spajanja, propisuju da imovina društava koje prestaje prelazi na društvo preuzimatelja ili novoosnovano društvo. Time društvo preuzimatelj ili novoosnovano društvo ulaze 
u dosadašnja prava i obveze društava koja prestaju. ${ }^{24}$ Prema odredbi § 69. a stavak 1. slovačkoga TZ-a, trenutak nastanka spomenutih posljedica upis je pripajanja ili spajanja u slovački trgovački registar (slov. obchodný register). Promjena na strani dosadašnjega dužnika nastaje ex lege i slično kao u poljskom uređenju, te za nju nije potreban pristanak vjerovnika i u vezi s tim ne dolazi do promjene načina preuzimanja duga propisanog u odredbi § 531. slovačkoga Građanskog zakonika.

U slovačkoj se pravnoj literaturi ističe da zbog prekograničnoga pripajanja $\mathrm{i}$ spajanja aktive i pasive društava koja prestaju u pravilu će prelaziti na društvo preuzimatelja ili novoosnovano društvo. ${ }^{25} \mathrm{Za}$ razliku od poljskoga uređenja, slovački je zakonodavac propisao u odredbi članka $\S 69$. aa stavak 2. toč. e TZ-a da se u sklopu plana ugovora o prekograničnom pripajanju ili spajanju (slov. návrh zmluvy o cezhraničnom zlúčení alebo splynutí) moraju navesti podatci koji se odnose na imovinu koja prelazi na društvo preuzimatelja ili novoosnovano društvo.

\subsubsection{Obveze objavljivanja podataka društava koja sudjeluju $u$ prekograničnom pripajanju i spajanju}

Obveza objave plana ugovora o pripajanju (spajanju) stvara sljedeći mehanizam institucionalne zaštite interesa vjerovnika $u$ vezi $\mathrm{s}$ prekograničnim pripajanjem (spajanjem). Uređenje redoslijeda objavljivanja podataka o prekograničnom pripajanju (spajanju) u istom se stupnju razlikuje od uređenja koje vrijedi u poljskom zakonodavstvu. Nužno je istaknuti da u smislu odredaba slovačkoga Trgovačkog zakonika, društvo kapitala koje sudjeluje u prekograničnom pripajanju ili spajanju, obvezno je sastaviti dvije objave koje slijede jedna za drugom: objava plana ugovora o prekograničnom pripajanju ili spajanju (\$69. aa st. 3 slovačkog TZ-a) te objava podataka propisanih odredbom $\$ 69$. aa stavak 4. slovačkoga TZ-a u svojem sjedištu ili na mrežnoj stranici. Dakle, u slovačkom pravu nije bila predviđena expressis verbis mogućnost odstupiti od tradicionalnog načina objavljivanja plana ugovora o prekograničnom pripajanju ili spajajnju.

Prema odredbi §69. aa stavak 3. toč. c slovačkog-a TZ-a, slovačko društvo koje sudjeluje u pripajanju i spajanju obvezno je najmanje mjesec dana prije glasovanja o prekograničnom pripajanju ili spajanju objaviti, uz plan ugovora o prekograničnom pripajanju ili spajanju i podatak o tome koji su pravni koraci poduzeti u svrhu osiguravanja prava vjerovnika zajedno s adresom ili mrežnom adresom na kojoj mogu besplatno dobiti obavijesti o tome. ${ }^{26}$ Ova odredba vrijedi za slovačko društvo kapitala koje sudjeluje u prekograničnom pripajanju ili spajanju.

\subsubsection{Javnobilježnička $i$ sudska kontrola prekograničnog pripajanja ili spajanja}

Isto kao i u poljskom zakonodavstvu, kontrolna etapa u slučaju prekograničnog

24 Vidi: Bartová, u: Patakyová et al., Obchodný zákonnik. Komentár, (Bratislava: C.H. Beck, 2010.), § 69 ObZ, 232.

25 Pala, Palová, Leontiev, Cezhraničné fúzie, 147.

26 Pala, Palová, Leontiev, Cezhraničné fúzie, 185. 
pripajanja i spajanja provodi se u dva koraka. Razlika je u odnosu na poljsko uređenje ta što prvu etapu kontrole provodi javni bilježnik. Međutim, drugi dio kontrole obavlja slovački registarski sud uz uvjet da će društvo preuzimatelj ili novo društvo imati svoje sjedište na području Republike Slovačke.

U slovačkoj se literaturi ističe da se u tom slučaju zaštita interesa vjerovnika društva koje sudjeluje u prekograničnom pripajanju ili spajanju ostvaruje putem mogućnosti izdavanja potvrde o zakonitosti takvoga prekograničnog postupka. ${ }^{27}$ Izdavanje potvrde ovisi upravo o poduzimanju pravnih koraka slovačkoga društva koje ima za cilj osiguravanje prava njegovih dotadašnjih vjerovnika. Mogući spor između društva i vjerovnika koji bi se odnosio na davanje osiguranja tražbine može riješiti samo sud. Valja imati na umu da javni bilježnik neće moći izdati spomenutu potvrdu ako postupci koji se tiču davanja osiguranja vjerovnikovim tražbinama, o kojim je bio informiran, nisu bili pravomoćno završeni. ${ }^{28}$ Nužno je istaknuti da vjerovnici ne prijavljuju postojanje njihovih tražbina javnom bilježniku, već samo podatak da je postupak u predmetu njihova eventualnoga osiguranja bio započet. ${ }^{29}$

\section{INSTRUMENTI INDIVIDUALNE ZAŠTITE}

\subsection{Poljska regulacija}

\subsubsection{Pravo prvenstvenog namirenja iz imovine društva dužnika}

Poljski je zakonodavac u odredbi članka 496. ZoTD-a propisao pravilo, prema kojem vjerovnik svakog društva koje sudjeluje u pripajanju i spajanju ima pravo prvenstvenog namirenja iz imovine toga društva prije vjerovnika iz ostalih društava koja sudjeluju u tom postupku. Spomenutu odredbu nužno je tumačiti kao pravo vjerovnika, a ne kao njegovu obvezu. ${ }^{30}$ Ovom se odredbom ne predviđa apsolutan redoslijed namirenja vjerovnikovih tražbina, ali se pruža mogućnost namiriti tražbine od tih vjerovnika društava koja se pripajaju ili spajaju s društvima koja imaju lošije financijsko stanje. Nadalje, ti vjerovnici mogu jednostavno nakon dana provođenja pripajanja ili spajanja tražiti od društva pravnoga sljednika namirenje svoje tražbine bez ukazivanja na imovinu iz koje bi imali biti namireni. Odredba prvenstvenog namirenja koju je propisao poljski zakonodavac jamči da vjerovnici mogu postići namirenje iz imovine njihova prvobitnog dužnika prije vjerovnika ostalih društava koja sudjeluju u pripajanju ili spajanju.

Spomenuta odredba članka 496. ZoTD-a služi trenutačnoj zaštiti vjerovnika poljskih društava koja sudjeluju u prekograničnim pripajanjima i spajanjima.

27 Pala, Palová, Leontiev, Cezhraničné fúzie, 186.

28 Pala, Palová, Leontiev, Cezhraničné fúzie, 186 te Bartová, u: Patakyová et al., Obchodný zákonnik. Komentár, (Bratislava: C.H. Beck, 2010.) § 69aa ObZ, 249.

29 Bartová, u: Patakyová et al., Obchodný zákonník. Komentár, (Bratislava: C.H. Beck, 2010.) § 69aa ObZ, 250.

30 Pinior, u: Strzępka, (ur.), Kodeks spótek handlowych. Komentarz (Warszawa: C.H. Beck, 2015.), Art. 496 KSH Nb. 1, 1210; Rodzynkiewicz, u: Opalski, (ur.), Kodeks spótek handlowych. Komentarz (Warszawa: C.H. Beck, 2016.), Art. 496 KSH Nb. 1, 147; Fliszkiewicz, Ochrona wierzycieli łączacych się spółek kapitałowych, 244. 
Međutim, u smislu odredbe članka 516(10). § 1. ZoTD-a ovo se uređenje primjenjuje i na slučajeve u kojima će radi prekograničnog pripajanja ili spajanja društvo preuzimatelj ili novoosnovano društvo biti društvo kapitala za koje je mjerodavno poljsko pravo. Subjekti ovlašteni koristiti prvenstveno pravo namirenja bit će vjerovnici društava koja sudjeluju u spajanjima, pa i vjerovnici društva preuzimatelja i pripojenog društva. To ne znači da će svaki vjerovnik društva moći koristiti to pravo. Nužno je istaknuti da se pravo prvenstvenog namirenja odnosi samo na prvobitne vjerovnike, tj. one čije su tražbine postojale prije dana provođenja pripajanja ili spajanja. S jedne strane, u vezi s univerzalnom sukcesijom do koje dolazi pripajanjem i spajanjem, društvo preuzimatelj ili novoosnovano društvo stječe pravo na slobodno korištenje dijelovima imovine koje će prijeći na njega. S druge strane, slobodno korištenje tih dijelova imovine ovisit će o tome jesu li vjerovnici, čije su tražbine postojale prije dana provođenja pripajanja ili spajanja, koristili prvenstveno pravo namirenja. U vezi s tim, nužno je voditi računa da se tražbine nastale nakon dana provođenja pripajanja ili spajanja, mogu namiriti iz dijelova imovine koje je ranije držalo bilo koje društvo koje sudjeluje u pripajanju ili spajanju. ${ }^{31}$

Poljski je zakonodavac istaknuo expressis verbis da se pravo prvenstvenog namirenja može ostvariti tijekom odvojenog upravljanja imovinama društava koja sudjeluju u pripajanjima ili spajanjima. Drugim riječima, odredba članka 496. § 1 . ZoTD-a funkcionalno je povezana s odredbom članka 495. § 1. ZoTD-a. Slijedom toga bi trebalo pretpostaviti da prvenstveno pravo namirenja postoji od dana provođenja pripajanja, odnosno spajanja. Vjerovnici bi ga de facto mogli učinkovito ostvarivati tek nakon trenutka kada su pismeno zatražili isplate. Vjerovnikov zahtjev može biti podnesen najkasnije šest mjeseci od dana objave prekograničnog pripajanja ili spajanja. Terminus ad quem za ostvarivanje prava namirenja iz imovine prvobitnog dužnika s prvenstvom prije ostalih vjerovnika jest dan kada su svaki od vjerovnika, koji su prema članku 495. $§ 1$. ZoTD-a podnijeli pisani zahtjev, bili namireni ili osigurani od društva preuzimatelja ili novoga društva.

Nastavno na zauzeta stajališta, svi će vjerovnici moći steći prvenstveno pravo, već ako najmanje jedan od njih postavi zahtjev za isplatu prema članku 495. § 1 . ZoTD-a. ${ }^{32}$ Nadalje, mogućnost da vjerovnik koristi prvenstveno pravo namirenja tražit će vjerovnikovu aktivnu radnju. U njegovom će interesu biti ostvarenje namirenja iz imovine njegova prvobitnog dužnika ili će namirenje iz imovine prvobitnog dužnika biti za njega drugostupanjsko pitanje. Dakle, vjerovnici mogu nakon dana provođenja pripajanja ili spajanja tražiti, da društvo koje je pravni sljednik podmiri njihove tražbine bez navođenja imovine iz koje bi mogli biti

31 Usporedi o doktrini trgovačkog prava u međuratnom razdoblju: Tadeusz Dziurzyński, Zygmunt Fenichel, Mieczyslaw Honzatko, Kodeks handlowy. Komentarz. Tom I, Kraków: Ksiegarnia powszechna, 1936., 469.

32 Cf. Szumański, u: Stanisław Sołtysiński et al., Kodeks spótek handlowych. Komentarz. Tom IV. (Warszawa: C.H. Beck, 2012.) Art. 496 KSH Nb. 11, 132; Pinior, u: Strzępka (ur.), Kodeks spółek handlowych. Komentarz, (Warszawa: C.H. Beck, 2015.), Art. 496 KSH Nb. 1, 1210; Jan Namitkiewicz, Kodeks handlowy. Komentarz. Tom III. Spótka z ograniczona odpowiedzialnościa, (Warszawa: 1937.), 340. Drugačije to shvaćaju: Dziurzyński, Fenichel i Honzatko, Kodeks handlowy. Komentarz. Tom I., 469. 
namireni. Odredba članka 496. §1. ZoTD-a uređuje na taj način pravo vjerovnika, a ne njegovu obvezu.

\subsubsection{Pravo na zahtijevanje davanja osiguranja tražbina}

Mogućnost da vjerovnici iskoriste protiv društva pravo zahtijevati osiguranje tražbina traži njihovo aktivno djelovanje u cilju učinkovitog ostvarivanja. U vezi s tim nužno je navesti da to pravo spada $u$ instrumente individualne zaštite interesa vjerovnika. Njegov je temelj u načelu propisan člankom 99. stavkom 2. Direktive (EU) Europskog parlamenta i Vijeća od 14. lipnja 2017. o određenim aspektima prava društava. ${ }^{33}$

S obzirom na poljski regulatorni okvir prekograničnih pripajanja ili spajanja, zaključuje se da će pravo vjerovnika zahtijevati davanje osiguranja biti drukčije ostvareno ako je društvo preuzimatelj ili novoosnovano društvo poljsko društvo kapitala, a sasvim drukčije kad društvo preuzimatelj ili novoosnovano društvo jest inozemno društvo kapitala. U prvoj će se situaciji primijeniti odredba članka 496. $\S 2$. ZoTD-a (argument a contrario iz odredbe članka 516(10). § 1. ZoTD-a). U drugom slučaju nužno je izravno primijeniti članak 516(10). § 2. i 3. ZoTD-a.

Prema odredbi članka 496. $\S 2$. ZoTD-a, vjerovnici društva koje sudjeluje u pripajanju ili spajanju mogu zahtijevati da im nadležan sud, u čijem je registru upisano društvo preuzimatelj ili će biti upisano novo društvo, pruži primjereno osiguranje, ako društvo preuzimatelj ili novo društvo nije dalo osiguranje. U spomenutoj odredbi riječ je o vjerovnicima društva preuzimatelja ili pripojenog društva te društva koje sudjeluje u spajanju. Nužno je istaknuti da na temelju ove odredbe ovo pravo mogu iskoristiti i vjerovnici poljskoga društva preuzimatelja ili poljskoga pripojenog društva i vjerovnici poljskoga društva koje sudjeluje u spajanju, ako će provođenjem prekograničnog pripajanja novo društvo imati svoje sjedište na području Republike Poljske. To će pravo moći iskoristiti i vjerovnici inozemnog društva ako kod prekograničnog pripajanja ili spajanja društvo preuzimatelj ili novo društvo bude poljsko društvo kapitala. Smatra se da odredba članka 496. § 2. ZoTD-a ne obuhvaća buduće (sasvim nove) vjerovnike novoosnovanog društva, jer su tražbine koje mogu biti osigurane morale još postajati prema društvu koje je sudjelovalo u spajanju.

Ovlašteni vjerovnici na temelju odredbe članka 496. § 2. ZoTD-a mogu zahtijevati osiguranje iz cijele imovine društva preuzimatelja ili novog društva, a ne samo iz imovine prvobitnog dužnika. Ovo je pravo neovisno o pravu propisanom u odredbama članka 495. i 496. § 1. ZoTD-a. ${ }^{34}$ Kako bi vjerovnici stekli primjereno osiguranje, vjerovnik mora posvetiti dužnu pažnju dvjema činjenicama: prijavi tražbine te dokazivanju da je pripajanjem ili spajanjem ugroženo ispunjavanje njihove tražbine.

33 Direktiva Europskog parlamenta i Vijeća (EU) 2017/1132 od 14. lipnja 2017. o određenim aspektima prava društava, Službeni list br. 169, 30. lipnja 2017

34 Vidi: Pinior, u: Strzępka (ur.), Kodeks spółek handlowych. Komentarz (Warszawa: C.H. Beck, 2015.), Art. 496 KSH Nb. 5,, 1211 te Oplustil, u: Bieniak et al., Kodeks spótek handlowych. Komentarz (Warszawa: C.H. Beck, 2015.), Art. 496 KSH Nb. 5, 1148. 
Ako je kod prekograničnog pripajanja ili spajanja društvo preuzimatelj ili novoosnovano društvo inozemno društvo, neće biti primijenjena odredba članka 496. $\S 2$. ZoTD-a. Poljski je zakonodavac pritom propisao u odredbi članka 516(10).§ 2. te 3. ZoTD-a zaštitu interesa vjerovnika poljskoga pripojenog društva te društva koje sudjeluje u spajanju. Prema odredbi članka 516(10). § 2. ZoTD-a vjerovnik tuzemnog društva može u roku od mjeseca dana, od objave plana pripajanja (spajanja) zahtijevati osiguranje svoje tražbine, ako dokaže da je prekograničnim pripajanjem ili spajanjem ugroženo ispunjavanje njegove tražbine. Ako dođe do spora između vjerovnika i društva o tom pitanju, nadležan sud u čijem je registru upisano poljsko pripojeno društvo ili društvo koje sudjeluje u spajanju bit će ovlašten donijeti meritornu odluku o davanju osiguranja (čl. 516(10). § 3. ZoTD-a). Vjerovnik poljskoga društva može biti i tuzemni i inozemni vjerovnik.

Poljski zakonodavac nije predvidio oblik za podnošenje ovoga zahtjeva društvu. Zbog toga se smatra da se zahtjev za osiguranje tražbine protiv društva može dati u bilo kojem obliku. Treba jednako prihvatiti da bi prijava zahtjeva za osiguranje tražbina bila obavljena u dokaznom obliku (ad probationem). Slično kao i kod odredbe članka 496. $\S 2$. ZoTD-a valja primijetiti da odredba članka 516(10). $\S 2$. ZoTD-a obuhvaća tražbine materijalnopravnog karaktera koje proizlaze iz građanskog prava.

Prema odredbi članka 516(10). § 3. ZoTD-a u slučaju spora između vjerovnika i poljskoga društva koje sudjeluje u prekograničnim pripajanjima ili spajanjima, kada je pravni sljednik ovog društva inozemno društvo, postoji mogućnost da bi sud odlučio i obvezao društvo na davanje osiguranja u korist vjerovnika. Time dolazi do analogne situacije kao u osiguravanju tražbina vjerovnika u tuzemnim spajanjima i pripajanjima. Vjerovnikov zahtjev mora biti podnesen u roku od dva tjedna nakon objave plana pripajanja, odnosno spajanja. Mora se smatrati da spomenuti rok ima karakter prekluzivnoga roka, i u slučaju njegova prekoračenja, zahtjev se neće moći podnijeti.

\subsection{Slovačka regulacija}

\subsubsection{Pravo zahtijevati davanje osiguranja tražbina}

Određivanje instrumenta koji služe individualnoj zaštiti vjerovnikovih interesa različito je u slovačkom i poljskom pravu. Ponajprije u slovačkom pravu nije regulirano prvenstveno pravo namirenja tražbina iz imovine društva koje je bilo prvobitan dužnik danog vjerovnika. Međutim, u odnosu na pravo vjerovnika da zahtijeva davanje osiguranja protiv društva, slovački zakonodavac, slično kao poljski, propisao je pravo osiguranja tražbina vjerovnika ako društvo preuzimatelj ili novoosnovano društvo bude slovačko društvo ( $\$ 218$. f st. 1 . te $\S 69$. aa st. 5. slovačkoga TZ-a) te pravo osiguranja tražbina vjerovnika ako je društvo preuzimatelj ili novoosnovano društvo inozemno društvo (§ 69. aa st. 5. slovačkoga TZ-a). Pravo osiguranja tražbina, iako izravno proizlazi iz odredaba slovačkoga Trgovačkog zakonika, zahtijeva aktivno djelovanje vjerovnika slovačkog društva koji sudjeluje u prekograničnom pripajanju, odnosno spajanju. Zaštita njegovih interesa može biti 
ostvarena tek nakon što poduzme određene radnje.

U smislu odredbe § 218. f stavak 1. slovačkoga TZ-a, vjerovnici, koji su imali u trenutku upisa pripajanja (spajanja) nedospjele tražbine i ako su ih prijavili u roku od šest mjeseci od dana ovog upisa, imaju pravo tražiti da društvo preuzimatelj ili novo društvo pruži osiguranje za ove tražbine, ako se mogućnost da budu namirene pogoršala zbog pripajanja ili spajanja. Slovački je zakonodavac naveo kao trenutak od kojega teče šestomjesečni rok za prijavu zahtjeva za osiguranje, dan upisa pripajanja (spajanja) u registar. Ovo je znatna razlika u usporedbi s primjenom članka 496. § 2. ZoTD-a, koji kao početak roka određuje dan provođenja pripajanja ili spajanja. Slovački zakonodavac propisao je prekluzivni rok i nakon njegova isteka, pravo da vjerovnik zahtijeva osiguranje svoje tražbine neće biti ostvareno. ${ }^{35}$

Društvo koje je dužno dati osiguranje slovačko je društvo preuzimatelj ili slovačko novoosnovano društvo. Tek kada vjerovnik i društvo ne postignu sporazum u skladu s odredbom $\S 215$. stavak 4. slovačkoga TZ-a o osiguranju će odlučivati sud. Mjesna će se nadležnost suda u pravilu određivati prema sjedištu slovačkoga društva preuzimatelja ili novog društva.

Vjerovnik slovačkoga društva preuzimatelja ili novoosnovanog društva može uz to iskoristiti pravo propisano u odredbi § 69. aa stavak 5. slovačkoga TZa. Ovaj oblik osiguranja odnosi se samo na prekogranična pripajanja i spajanja i ne primjenjuje se na tuzemna pripajanja i spajanja. Nevažna je razlika hoće li biti društvo preuzimatelj ili novo društvo radi prekograničnog pripajanja ili spajanja inozemno ili slovačko društvo kapitala. ${ }^{36}$ Ovo pravo počiva na mogućnosti da će vjerovnik koji je na dan sklapanja projekta ugovora o prekograničnom pripajanju ili spajanju imao nedospjele tražbine zahtijevati da njegove tražbine primjereno osigura (slov. primerane zabezpečené) slovačko društvo - dužnik. To se pravo može ostvariti samo protiv slovačkog društva koje sudjeluje u prekograničnim spajanjima ili pripajanjima (društva preuzimatelja ili pripojenog društva).

\section{ZAKLJUČAK}

Nužno je istaknuti da su odredbe koje imaju svrhu zaštititi interes vjerovnika važan element $u$ postupku pripajanja i spajanja. Otvoreno pitanje $u$ analizi opisane problematike je jamčiti vjerovnicima takvu zaštitu gdje za društvo koje sudjeluje u pripajanju ili spajanju neće biti nametnute prekomjerne obveze. Iako temeljna odredba kojom se pruža zaštita interesa vjerovnika uređuje odredba članka 99. Direktive (EU) 2017/1132, pojedina nacionalna zakonodavstva uvode niz vlastitih instrumenta koja služe zaštiti interesa vjerovnika. Bez obzira na to, države članice su obvezne zajamčiti odgovarajući sustav zaštite interesa vjerovnika društava koja sudjeluju u spajanjima i pripajanjima te čije su tražbine nastale prije objave plana pripajanja ili spajanja i u vrijeme te objave još nisu dospjele. Valja istaknuti da se

35 Pala, Palová i Leontiev, Cezhraničné fúzie, 188 te Palová, Pala i Žitňanská, u:Ovečková, et. al, Obchodný zákonnik. Komentár. 1. Čast', (Bratislava: Iura Edition 2012.) §218f ObZ, 999.

36 Vidi: Bartová, u: Patakyová et al., Obchodný zákonnik. Komentár, (Bratislava: C.H. Beck, 2010.) § 69aa ObZ 248. 
minimalan standard zaštite odnosi na događaje prije trenutka kada je vjerovnik mogao dobiti informaciju o planiranom pripajanju ili spajanju.

Uzimajući u obzir način ostvarivanja zaštite prava vjerovnika, instrumenti koji služe zaštiti mogu imati dvije razine: individualnu i instrumentalnu. Institucionalna zaštita ima zaštitni karakter i ne zahtijeva u načelu aktivno djelovanje vjerovnika za njezinu realizaciju. Individualna zaštita, međutim, izravno služi za osiguravanje ili namirenje tražbina vjerovnika i zahtijevat će aktivno djelovanje vjerovnika prema društvu.

\section{Knjige i članci}

\section{LITERATURA}

1. Bieniak, Jacek, Michał Bieniak, Grzegorz Nita-Jagielski, Krzysztof Oplustil, Robert Pabis, Anna Rachwał, Marcin Spyra, Grzegorz Suliński, Marcin Tofel, Kodeks spótek handlowych. Komentarz. Warszawa: C.H. Beck, 2015.

2. Dziurzyński Tadeusz, Zygmunt Fenichel, Mieczysław Honzatko. Kodeks handlowy. Komentarz. Tom I., Kraków: Ksiegarnia powszechna, 1936.

3. Fliszkiewicz, Krzysztof. Ochrona wierzycieli łaczacych się spółek kapitałowych. Warszawa: C.H. Beck, 2016.

4. Jara, Zbigniew (ur.). Kodeks spółek handlowych. Komentarz, Warszawa: C.H. Beck, 2014.

5. Kalls, Susanne. „Gläubigerschutz bei Verschmelzungen von Kapitalgesellschaften“. Zeitschrift für Unternehmens- und Gesellschaftsrecht, br. 1 (2009): 74-125.

6. Katner, Wojciech Jerzy i Krzysztof Fliszkiewicz. „, Łaczenie się $i$ inne rodzaje transformacji spótek ze szczególnym uwzględnieniem ochrony wierzycieli taczacych się spółek kapitałowych (prawo polskie na tle prawa Unii Europejskiej)" u: Józef Frąckowiak (ur.). Kodeks spótek handlowych po dziesięciu latach. Wrocław: Wydawnictwo Uniwersytetu Wrocławskiego, 2013.

7. Kidyba, Andrzej (ur.). Meritum. Prawo spółek. Tom II, Warszawa: Wolters Kluwer Polska, 2013.

8. Namitkiewicz, Jan. Kodeks handlowy. Komentarz. Tom III. Spółka z ograniczona odpowiedzialnościa, Warszawa: 1937.

9. Opalski, Adam (ur.). Kodeks spótek handlowych. Tom IV. Łaczenie, podziat, przekształcanie spółek. Przepisy karne. Komentarz, Warszawa: C.H. Beck, 2016.

10. Ovečková Ol'ga, Alena Černejová, L’udmila Lacová, Mária Majeriková, Radovan Pala, Ivana Palová, Mária Patakyová, Jozef Vozár, Lucia Žitňanská. Obchodný zákonník. Komentár. 1. Čast', Bratislava: Iura Edition, 2012.

11. Pala, Radovan, Ivana Palová, Andrej Leontiev. Cezhraničné fúzie, Bratislava: C.H. Beck, 2010.

12. Patakyová, Maria, Zuzana Bartová, Marián Blaha, Milan Durica, Branislav Jablonka, Timea Kováčsová, Andrea Moravčíková i Jozef Vozár, Obchodný zákonník. Komentár. Bratislava: C.H. Beck, 2010.

13. Sołtysiński, Stanisław, Andrzej Szajkowski, Andrzej Szumański, Janusz Szwaja, Monika Tarska, Robert Zawłocki, Kodeks spółek handlowych. Komentarz. Tom IV, Warszawa: C.H. Beck, 2012.

14. Strzępka, Janusz Andrzej (ur.). Kodeks spółek handlowych. Komentarz, Warszawa: C.H. Beck, 2015.

15. Witosz, Antoni, Łączenie się i podziat spótek w Kodeksie spótek handlowych, Bydgoszcz: Branta, 2002. 
16. Żaba, Mateusz, Skutki transgranicznego łaczenia się spótek kapitałowych (studium prawnoporównawcze ustawodawstwa polskiego, czeskiego i stowackiego), Warszawa: C.H. Beck, 2019.

\section{Pravni akti}

1. Deseta direktiva 2005/56/EZ Europskog parlamenta i Vijeća od 26. listopada 2005. o prekograničnim pripajanjima i spajanjima društava kapitala, Službeni list br. 310, od 25. studenoga 2005.

2. Direktiva Europskog parlamenta i Vijeća (EU) 2017/1132 od 14. lipnja 2017. o određenim aspektima prava društava, Službeni list br. 169, 30. lipnja 2017.

3. Treća direktiva Vijeća od 78/855/EEZ od 9. listopada 1978. o spajanjima dioničkih društava, Službeni list br. 295 od 20. listopada 1978.

4. Ustawa z 23.04.1964 - Kodeks cywilny od 23. ožujka 1964. - Dz. U. Nr 16, poz. 93 ze zm.

5. Ustawa z 27.06.1934 r. - Kodeks handlowy od 27. lipnja 1934. - Dz. U. z 1934 r., nr 57, poz. 502 wraz ze zm.

6. Ustawa z 15.08.2000 r. - Kodeks spółek handlowych od 15. kolovoza 2000. - Dz. U. z 2000 r., nr 94, poz. 1037 wraz ze zm.

7. Zákon z 5.11.1991 - Obchodný zákonník od 5. studenoga 1991. Zák. č. 513/1991 Z. z. 


\section{Mateusz Żaba*}

Summary

\section{INSTRUMENTS FOR THE PROTECTION OF CREDITORS OF COMPANIES PARTICIPATING IN CROSS-BORDER MERGERS AND ACQUISITIONS IN POLISH AND SLOVAK LAW}

Cross-border mergers and acquisitions are increasingly becoming a matter of concern for legal sciences in the Member States. Enabling of the procedures of conducting mergers and acquisitions between companies from different states realises the concept of the single market within the European Union. The conducting of cross-border acquisitions or mergers carries with it a number of legal consequences, and influences the position of existing creditors of companies participating in this procedure. In view of this, the mechanisms that serve to protect the creditors' interests of the company participating in the merger and acquisition are presented in this paper. The scope of the research involves Polish and Slovak legal orders. The choice of these legal orders was made considering that in the last thirty years these countries have undergone the transformation of the state system, created new opportunities for undertaking business activity within the free market economy, and finally acceded to the European Union on May $1^{\text {st }} 2004$. The article focuses primarily on the two grounds of protection of creditors' interests i.e. the institutional and the individual ground. In several chapters' instruments such as the liability of the successor company for liabilities; separate management of the assets; the priority right to satisfy from assets of the debtor company and the right to demand a suitable security for the claims are presented.

Keywords: cross-border acquisition; cross-border merger; creditor protection; Polish law; Slovak law; institutional protection of interests of company's creditors; individual protection of interests of company's creditors.

* Mateusz Żaba, Ph.D., Assistant Professor, Faculty of Law and Administration, University of Silesia in Katowice; mateusz.zaba@us.edu.pl. ORCID: https://orcid.org/0000-0002-36366456. 
